\title{
KAJIAN PEMBEBASAN LAHAN OLEH PT. PERTAMINA GHEOTERMAL ENERGY TERHADAP NILAI LAHAN DI DESA TONSEWER SELATAN KECAMATAN TOMPASO BARAT
}

\author{
Steisi A. Mamesah \\ Mex Frans Lodwyk Sondakh \\ Yolanda Pinky Ivanna Rori
}

\begin{tabular}{ll}
\hline Naskah diterima melalui Email Jurnal Ilmiah agrisosioekonomi@unsrat.ac.id & : Rabu, 29 Januari 2020 \\
Disetujui diterbitkan & $:$ Jumat, 29 Mei 2020 \\
\hline
\end{tabular}

\begin{abstract}
This study aims to determine the value of land that has been released whether it affects the value of land and determine the use of money from land acquisition in Tonsewer Selatan Village, Tompaso Barat Sub-district. This research was conducted in three months, from September to November 2019. The sampling method in this study uses a non-probability sampling technique or census sampling. The samples used in this study were 13 respondents, namely all farmers who own agricultural land who have sold their land so that land conversion has occurred. In this study using primary data obtained from direct interviews with respondents using a list of questions that have been prepared. Secondary data obtained from relevant agencies. The results showed that the value of the land acquired was higher in value than the present land value. This means that the value of land that has been acquired affects the current value of land. The money from the land acquisition has been used for various purposes, namely: for business capital, buying new land, saving, buying vehicles, renovating houses, and for daily needs. ${ }^{*}{ }^{2}{ }^{*}$
\end{abstract}

Keywords: land acquisition, land value, South Tonsewer Village

\begin{abstract}
ABSTRAK
Penelitian ini bertujuan untuk mengetahui nilai lahan yang telah dibebaskan apakah berpengaruh terhadap nilai lahan dan mengetahui pemanfaatan uang hasil dari pembebasan lahan yang ada di Desa Tonsewer Selatan Kecamatan Tompaso Barat. Penelitian ini dilakukan dalam selama tiga bulan yaitu bulan September sampai bulan November 2019. Metode Pengambilan sampel dalam penelitian ini menggunakan teknik non-probability sampling yakni sampling jenuh atau sensus. Sampel yang digunakan dalam penelitian ini sebanyak 13 orang reponden yakni semua petani pemilik lahan pertanian yang telah menjual lahannya sehingga telah terjadi alih fungsi lahan. Dalam penelitian ini menggunakan data primer yang diperoleh dari wawancara langsung dengan responden dengan menggunakan daftar pertanyaan yang telah disiapkan. Dalam penelitian ini metode analisis data yang digunakan adalah metode deskriptif. Data sekunder yang diperoleh dari instansi terkait. Hasil penelitian menunjukkan bahwa nilai lahan yang dibebaskan lebih tinggi nilainya dari pada nilai lahan sekarang. Artinya nilai lahan yang telah dibebaskan mempengaruhi nilai lahan sekarang. Uang hasil pembebasan lahan telah digunakan untuk berbagai keperluan yaitu: untuk modal usaha, membeli lahan baru, ditabung, membeli kendaraan, merenovasi rumah, dan untuk kebutuhan sehari-hari. ${ }^{* e p r m}{ }^{*}$
\end{abstract}

Kata kunci: pembebasan lahan, nilai lahan, Tonsewer Selatan Village

Agrisosioekonomi: 


\section{PENDAHULUAN}

\section{Latar Belakang}

Lahan selalu mengalami perubahan dari waktu ke waktu seiring meningkatnya kebutuhan manusia akan lahan. Perubahan tersebut dikarenakan pemanfaatan lahan untuk kepentingan manusia. Kebutuhan akan lahan non pertanian cenderung terus mengalami peningkatan, seiring pertumbuhan dan perkembangan peradaban manusia, maka penguasaan dan penggunaan lahan mulai beralih fungsi.

\section{Pengertian Lahan}

Manusia dalam hidupnya tidak dapat dipisahkan dari tanah. Tanah atau lahan yang merupakan sumber daya alam terpenting dalam menopang setiap aktivitas kehidupan manusia baik sebagai sumber daya yang dapat diolah atau sebagai tempat tinggal, namun karena sebidang lahan dapat dipergunakan untuk bermacammacam keperluan agar dapat memenuhi kebutuhan hidup, maka timbullah persaingan di dalam pemanfaatannya. Menurut Mamarrodia dalam Benu (2016), lahan merupakan sumber daya pembangunan yang memiliki karakteristik ketersediaan atau luasnya relatif tetap karena perubahan luas akibat proses alamiah (sedimentasi) dan proses artifisial (reklamasi) sangat kecil. Bagi petani lahan adalah tempat bercocok tanam dan sumber kehidupan, sedangkan bagi penduduk kota lahan adalah ruang untuk mendirikan bangunan seperti rumah, toko dan lain sebagainya.

Sifat-sifat lahan (land characteristic) adalah atribut atau keadaan unsur-unsur lahan yang dapat diukur atau diperkirakan, seperti tekstur tanah, struktur tanah, kedalaman tanah, jumlah curah hujan, distribusi hujan, temperatur, drainase tanah, jenis vegetasi dan sebagainya. Sifat-sifat lahan belum menunjukkan bagaimana kemungkinan penampilan lahan jika dipergunakan untuk suatu penggunaan, sehingga belum dapat menentukan kelas untuk kemampuan lahan. Akan tetapi sifat-sifat lahan yang menentukan atau mempengaruhi perilaku lahan yaitu bagaimana ketersediaan air, peredaran udara, perkembangan akar, kepekaan erosi, ketersedian unsur hara dan sebagainya. Perilaku lahan yang menentukan pertumbuhan tumbuhan tersebut disebut kualitas lahan (Lihawa, 2017).

\section{Penggunaan Lahan}

Penggunaan lahan merupakan, setiap bentuk campur tangan manusia terhadap sumber daya lahan baik yang bersifat menetap (permanen) maupun daur (siklus) yang bertujuan memenuhi kebutuhan hidupnya baik materil maupun spriritual (Pratama, 2016). Penggunaan lahan pada umumnya tergantung pada kemampuan lahan dan pada lokasi lahan. Untuk aktivitas pertanian, penggunaan lahan tergantung pada kelas kemampuan lahan yang dicirikan oleh adanya perbedaan atas sifat-sifat yang merupakan penghambat bagi penggunaannya, seperti tekstur tanah, lereng permukaan tanah, kemampuan menahan air, dan tingkat erosi yang telah terjadi.

Menurut Mokhamad 2015, Penggunaan lahan secara garis besar dibedakan menjadi dua golongan:

1. Dalam kaitannya dengan pemanfaatan potensi alami, seperti kesuburan tanah, kandungan mineral, atau terdapatnya endapan bahan galian pertambangan di bawah permukaannya.

2. Penggunaan tanah dalam kaitannya dengan pemanfaatannya sebagai ruang.

\section{Pembebasan Lahan}

Pembebasan lahan biasanya terkait dengan proses perkembangan suatu wilayah, bahkan dapat dikatakan bahwa pembebasan lahan merupakan konsekuensi dari perkembangan wilayah. Sebagian besar pembebasan lahan yang terjadi menunjukkan adanya ketimpangan dalam penguasaan lahan yang lebih didominasi oleh pihak kapitalis dengan mengantongi izin mendirikan bangunan yang dikeluarkan oleh pemerintah.

Alih fungsi lahan atau pembebasan lahan adalah perubahan fungsi sebagian atau seluruh kawasan lahan dari fungsinya semula (seperti yang direncanakan) menjadi fungsi lain yang menjadi dampak negatif (masalah) terhadap lingkungan dan potensi lahan itu sendiri. Dampak alih fungsi lahan juga mempengaruhi struktur sosial masyarakat, terutama dalam struktur mata pencaharian (Lestari, 2009) juga berpendapat bahwa konversi lahan merupakan ancaman yang serius bagi keberlanjutan fungsi lahan untuk pertanian, dan pada akhirnya juga akan berdampak terhadap ketahanan pangan nasional karena dampak perubahannya bersifat permanen. 
Menurut Firman dalam Wibisono, dkk (2018), bahwa alih fungsi lahan yang terjadi menimbulkan dampak langsung maupun dampak tidak langsung. Dampak langsung yang diakibatkan oleh alih fungsi lahan berupa hilangnya lahan pertanian subur, hilangnya investasi dalam infrasruktur irigasi, kerusakan natural lanskap, dan masalah lingkungan. Kemudian dampak tidak langsung yang ditimbulkan berupa inflasi penduduk dari wilayah perkotaan ke wilayah tepi kota. Kegiatan alih fungsi lahan juga berpengaruh terhadap lingkungan. Perubahan lahan pertanian menjadi non pertanian akan mempengaruhi keseimbangan ekosistem lahan pertanian. Menurut Ruswandi dalam Muhsin (2019), secara faktual alih fungsi lahan atau konversi lahan menimbulkan beberapa konsekuensi, antara lain berkurangnya lahan terbuka hijau sehingga lingkungan tata air akan terganggu, serta lahan untuk budidaya pertanian semakin sempit.

\section{Faktor Terjadinya Alih Fungsi Lahan}

Alasan utama petani melakukan alih fungsi lahan adalah karena kebutuhan lahannya berada dikawasan industri, serta harga lahan yang tinggi sehingga mendorong petani untuk menjual atau mengalih fungsikan lahannya. Proses terjadinya alih fungsi lahan pertanian menjadi non pertanian disebabkan oleh beberapa faktor. Menurut Lestari (2009), menyatakan bahwa setidaknya ada tiga faktor penting yang menyebabkan terjadinya alih fungsi lahan yaitu:

1. Faktor eksternal, disebabkan adanya dinamika pertumbuhan perkotaan (fisikmaupun sosial), demografi maupun ekonomi.

2. Faktor internal, disebabkan oleh kondisi sosial ekonomi rumah tangga pertanian dalam pengguna lahan.

3. Faktor kebijakan, disebabkan oleh aspek regulasi yang dikeluarkan pemerintah pusat maupun daerah yang berkaitan dengan perubahan fungsi lahan pertanian. Kelemahan terdapat pada aspek regulasi atau peraturan itu sendiri, terutama terkait dengan masalah kekuatan hokum dan objek lahan yang dilarang konversinya.

Alih fungsi lahan pertanian bukan merupakan hal yang baru. Dengan semakin meningkatnya taraf hidup dan terbukanya kesempatan untuk menciptakan peluang kerja, yang ditandai oleh semakin banyaknya investor ataupun masyarakat dan pemerintah dalam melakukan pembangunan, maka semakin meningkat pula kebutuhan akan lahan. Di pihak lain jumlah lahan yang terbatas menimbulkan penggunaan lahan yang beralih ke penggunaan non pertanian. Alih fungsi lahan pertanian menjadi non pertanian merupakan isu yang perlu diperhatikan karena ketergatungan masyarakat terhadap sektor pertanian.

\section{Peraturan Tentang Alih fungsi Lahan}

Landasan hukum dan kebijakan alih fungsi lahan pertanian UUPA antara lain:

1) Undang-undang Nomor 41 Tahun 2009 tentang Perlindungan Lahan Pertanian Pangan Berkelanjutan.

2) Undang-Undang Nomor 26 Tahun 2007 tentang penataan ruang. Undang-undang ini merupakan pengganti dari Undang-Undang Nomor 24 tahun 1992 tentang Penata Ruang yang menyebutkan bahwa RT/RW mempertimbangkan budidaya tanaman pangan dimana perubahan fungsi ruang kawasan pertanian menjadi kawasan pertambangan, pemukiman, kawasan industri, dan sebagainya memerlukan kajian dan penilaian atas perubahan fungsi ruang tersebut secara lintas sektor, lintas daerah, dan terpusat.

3) Peraturan Pemerintah Nomor 36 Tahun 2004 Tentang Penatagunaan Tanah.

4) Peraturan Pemerintah Nomor 36 tahun 1998 Tentang penertiban dan pendayagunaan lahan terlantar. Pasal 11 ayat (3b) yang berbunyi:" tanah yang diperoleh dasar penggunaannya oleh orang-perseorangan yang tidak menggunakan tanah tersebut sesuai keadaanya atau menurut sifat dan tujuan pemberian haknya atau tidak memelihara dengan baik atau tidak mengambil langkah-langkah pengelolaan bukan karena tidak mampu dari segi ekonomi, maka Kepala Kantor Pertanahan mengusulkan kepada Kepala Kantor Wilayah agar kepada pemegang hak diberi peringatan agar dalam waktu tertentu sudah menggunakan tanahnya sesuai keadaanya menurut sifat dan tujuan pemberian haknya".

5) Peraturan Menteri Agraria Nomor 2 Tahun 1999 Tentang Izin Lokasi. Pasal 6 ayat 1 yang berbunyi : "Izin lokasi diberikan berdasarkan pertimbangan mengenai aspek penguasaan tanah dan teknis tata guna tanah meliputi keadaan hak serta penguasaan tanah yang bersangkutan, penilaian fisik wilayah, penggunaan tanah, serta kemapuan tanah. 


\section{Nilai Lahan}

Nilai lahan merupakan kemampuan lahan secara ekonomis dalam hubungannya dengan produktivitas dan strategi ekonomis. Lahan memiliki nilai ekonomi dan nilai pasar yang berbeda-beda. Lahan di perkotaan yang digunakan untuk kegiatan industri dan perdagangan memiliki nilai pasar yang tertinggi karena di tempat tersebut terletak tempat tinggal dan sumber penghidupan manusia yang paling efisien dan memberikan nilai produksi yang tertinggi. Para pemilik sumber daya lahan cenderung menggunakan lahan untuk tujuan-tujuan yang memberikan harapan untuk diperolehnya penghasilan yang tertinggi. Mereka akan menggunakan lahannya sesuai dengan konsep penggunaan yang tertinggi dan terbaik. Konsep ini memperhitungkan semua faktor yang mempengaruhi kemampuan lahan, seperti aksesibilitas serta sumber daya lahan dan lingkungan. Harga lahan sangat dipengaruhi oleh parameterparameter nilai lahan, dimana semakin strategis lokasi lahan dengan fasilitas-fasilitas yang ada maka nilai lahan akan semakin tinggi.

Harga lahan sangat dipengaruhi parameter-parameter nilai lahan, dimana semakin strategis lokasi lahan dengan kota maka nilai lahan akan semakin tinggi. Nilai lahan semakin tinggi apabila dekat dengan pusat kegiatan, selain itu juga dipengaruhi oleh jarak dari pusat pelayanan, fasilitas kota, dan lain-lain. Faktor non manusia berkaitan dengan eksternalitas yang diterima oleh lahan tersebut, jika eksternalitas bersifat positif, seperti dekat dengan pusat perekonomian, bebas banjir, kepadatan penduduk, dan adanya sarana jalan, maka lahan akan bernilai tinggi jika dibandingkan dengan lahan yang tidak menerima eksternalitas, meskipun lusa dan bentuk tanah itu sama, jika lahan menerima eksternalitas yang bersifat negatif, seperti dekat dengan sampah, jauh dari pusat kota/perekonomian, maka lahan akan bernilain rendah jika dibandingkan dengan lahanlahan yang menerima eksternalitas yang positif.

Yunus (2017), memberi artian tentang nilai lahan ialah, pengukuran nilai lahan yang didasarkan kepada kemampuan lahan secara ekonomis dalam hubungannya dengan produktivitas dan strategi ekonomi. Nilai lahan adalah perwujudan dari kemampuan lahan yang berhubungan dengan pemanfaatan penggunaan lahan. Nilai lahan ini merupakan pendapat atau opini masyarakat terhadap harga suatu barang, oleh karena itu pendapat setiap orang tentang nilai suatu barang dapat berbeda. Menurut Zulkifli (2017), harga jual lahan yang diterima oleh petani dalam proses alih fungsi lahan secara signifikan dipengaruhi oleh status lahan, jumlah tenaga kerja yang terserap dilahan tersebut, jarak dari saluran tersier, jarak dari jalan, dan jarak dari kawasan industri atau pemukiman.

\section{Dampak Sosial Ekonomi}

Dampak sosial ekonomi adalah suatu perubahan yang muncul akibat adanya suatu kegiatan yang mempengaruhi lingkungan sosial masyarakat dan ekonomi, baik dalam hal kesempatan kerja, pendapatan, keresahan dan kesejahteraan masyarakat. Sullivan dalam Rahman (2015), menyatakan bila dipandang dari sudut pandang ekonomi, bertambahnya penduduk akibat adanya kegiatan di suatu wilayah akan meningkatkan pendapatan penduduk sekitar.

Dampak sosial menurut Ega (2018), dapat dikategorikan dalam dua kelompok, yaitu real impact dan special impact. Real impact adalah dampak yang timbul akibat adanya aktivitas proyek, pra konstruksi, kontruksi dan operasi. Misalnya pemindahan penduduk, kebisingan atau polusi udara. Special impact adalah suatu dampak yang timbul dari persepsi masyarakat terhadap resiko dari adanya proyek. Persepsi, sikap dan kepercayaan masyarakat membentuk interpretasi tentang dampak dari adanya kegiatan di suatu wilayah.

Desa Tonsewer Selatan merupakan salah satu desa yang mempunyai potensi untuk pembangunan pembangkit tenaga listrik oleh Pt. Pertamina Gheotermal Energy. Pada bulan Juni 2018 PT. Pertamina membeli lahan seluas 8,20 Ha untuk pembangunan proyek pembangkit tenaga listrik.

\section{Rumusan Masalah}

Berdasarkan latar belakang di atas, yang menjadi permasalahan dalam penelitian adalah bagaimana nilai lahan yang telah dibebaskan dan pemanfaatan uang hasil dari pembebasan lahan oleh PT. Pertamina Geothermal Energy di Desa Tonsewer Selatan Kecamatan Tompaso Barat?

\section{Tujuan Penelitian}

Penelitian ini bertujuan mengetahui nilai lahan yang telah dibebaskan dan pemanfaatan uang hasil dari pembebasan lahan oleh PT. Pertamina Geothermal Energy di Desa Tonsewer Selatan Kecamatan Tompaso Barat. 


\section{Manfaat Penelitian}

Penelitian ini dapat bermanfaat memberikan gambaran kepada pihak-pihak terkait tentang perubahan nilai lahan dengan adanya perubahan fungsi lahan dan menjadi referensi kajian dalam bidang penelitian serupa.

\section{METODE PENELITIAN}

\section{Waktu dan Tempat Penelitian}

Penelitian ini di laksanakan di Desa Tonsewer Selatan Kecamatan Tompaso Barat. Penelitian ini dilakukan dalam selama tiga bulan yaitu bulan September sampai bulan November 2019, yang dimulai dari persiapan sampai penyusunan laporan.

\section{Pengambilan Data}

Dalam penelitian ini menggunakan data primer yang diperoleh dari wawancara langsung dengan responden dengan menggunakan daftar pertanyaan yang telah disiapkan. Serta data sekunder yang diperoleh dari instansi terkait.

\section{Pengambilan Sampel}

Pengambilan sampel dalam penelitian ini menggunakan teknik non probability sampling yakni sampling jenuh atau sensus, yaitu metode penarikan sampel bila semua anggota populasi dijadikan sebagai sampel. Hal ini sering dilakukan apabila jumlah populasi kecil, kurang dari 30 orang (Supriyantto dan Machfudz, 2010). Sempel yang digunakan dalam penelitian ini sebanyak 13 orang reponden yakni petani mantan pemilik lahan pertanian yang telah melakukan alih fungsi lahan.

\section{Konsep Pengukuran Variabel}

Variabel-variabel yang akan diukur dalam penelitian ini adalah:

1. Karakteristik Responden
1) Nama
2) Umur
3) Tingkat Pendidikan
4) Pekerjaan

2. Jumlah Tanggungan KeluargaData lahan

1) Luas Lahan yang dimiliki

2) Luas Lahan yang dibebaskan

3) Harga Jual Lahan per $m^{2}$

4) Harga Lahan sekarang per $m^{2}$

3. Alasan Menjual Lahan

4. Pemanfaatan uang hasil pembebasan lahan

\section{Metode Analisis Data}

Dalam penelitian ini metode yang digunakan adalah metode deskriptif. Teknik analisis data yang menggunakan tabel agar mudah dimengerti dan di interpretasikan, serta menyusun dan menyajikan data menjadi informasi yang jelas. Dimana data yang diperlukan berasal dari hasil jawaban atas pertanyaan yang diajukan kepada responden dalam bentuk kuesioner.

\section{HASIL DAN PEMBAHASAN}

\section{Gambaran Umum Lokasi Penelitian}

Desa Tonsewer Selatan merupakan salah satu desa yang terletak di wilayah Kecamatan Tompaso Barat, Kabupaten Minahasa, Provinsi Sulawesi Utara. Desa Tonsewer Selatan memiliki luas wilayah 112 Ha dengan jarak dari pusat pemerintahan kecamatan 2,5 km, jarak ke pusat pemerintahan kabupaten $28 \mathrm{~km}$, dan jarak ke pusat pemerintahan provinsi $51 \mathrm{~km}$. Terdiri dari 4 Jaga, dengan batas wilayah :
1. Sebelah Utara
: Desa Tonsewer
2. Sebelah Timur
: Desa Touure Dua
3. Sebelah Selatan
: Gunung Soputan
4. Sebelah Barat
: Desa Pinabetengan Selatan

Sumber: Profil Desa Tonsewer Selatan, 2019

\section{Karakteristik Responden}

Desa Tonsewer Selatan memiliki jumlah penduduk sebesar 876 orang dengan jumlah lakilaki sebesar 453 dan perempuan sebesar 423 orang. Hal ini dapat dilihat pada Tabel 1.

Tabel 1. Jumlah Penduduk dan Persentase

\begin{tabular}{cccc}
\hline \multirow{2}{*}{ No } & $\begin{array}{c}\text { Jenis } \\
\text { Kelamin }\end{array}$ & $\begin{array}{c}\text { Jumlah Jiwa } \\
\text { (Orang) }\end{array}$ & $\begin{array}{c}\text { Persentase } \\
(\%)\end{array}$ \\
\hline 1. & Laki Laki & 453 & 52 \\
2. & Perempuan & 423 & 48 \\
\hline \multicolumn{5}{c}{ Sumber : Kantor Desa Tonsewer Selatan, 2019 }
\end{tabular}

\section{Karakteristik Responden Menurut Tingkat Umur}

Tingkat umur merupakan salah satu faktor yang mempengaruhi kemampuan seseorang dalam melakukan aktivitas maupun konsep berpikir. Responden yang berumur muda tentunya memiliki kondisi fisik lebih kuat dibandingkan dengan responden yang berumur tua. 


\begin{tabular}{lccc}
\multicolumn{5}{l}{ Tabel 2. Jumlah Responden Menurut Umur } \\
\hline \multirow{2}{*}{ No } & $\begin{array}{c}\text { Umur } \\
\text { (Tahun) }\end{array}$ & $\begin{array}{c}\text { Jumlah Responden } \\
\text { (Orang) }\end{array}$ & Persentase (\%) \\
\hline 1. & $30-40$ & 3 & 23.08 \\
2. & $41-50$ & 6 & 46.15 \\
3. & $51-60$ & 1 & 7.69 \\
4. & $61-70$ & 3 & 23.08 \\
\hline & Jumlah & 13 & 100 \\
\hline
\end{tabular}

Sumber: Diolah dari data Primer, 2019

Tabel 2 menunjukkan jumlah responden berumur 41-50 tahun, memiliki nilai persentase tertinggi yaitu 46,15 persen dengan 6 orang responden, Responden yang berumur 30-40 tahun, memiliki nilai persentase 23,08 persen dengan 3 orang responden hal ini sama halnya dengan responden yang berumur 61-70 tahun memiliki jumlah 3 orang responden dan presentase 23,08 persen. Dan yang responden yang berumur 51-60 tahun memiliki persentase 7,69 persen dengan 1 orang responden. Pada Tabel 2 ini dapat dilihat bahwa sebagian besar responden berada pada usia produktif, yaitu umur 41 sampai 50 tahun.

\section{Karakteristik Responden Menurut Tingkat Pendidikan}

Tingkat pendidikan responden dapat menunjukkan tingkat pengetahuan serta wawasan yang luas dari responden dalam menerapkan apa yang diperoleh untuk peningkatan usaha tani. Tingkat pendidikan petani dimana petani yang berpendidikan tinggi relatif lebih cepat dalam melaksanakan adopsi inovasi. Tingkat pendidikan yang rendah akan menurunkan produktivitas tenaga kerja yang akan dicapai, serta pendapatan yang diperoleh memiliki kecenderungan rendah. Melalui pendidikan seseorang memiliki pengetahuan yang luas, mudah mengembangkan ide-ide, mudah mengadopsi teknologi dan makin dinamis sikapnya terhadap hal-hal baru terutama dalam menghadapi perubahan yang lebih modern.

Tabel 3. Jumlah Responden Menurut Tingkat

\begin{tabular}{|c|c|c|c|}
\hline No & $\begin{array}{c}\text { Tingkat } \\
\text { Pendidikan }\end{array}$ & $\begin{array}{c}\text { Jumlah } \\
\text { Responden } \\
\text { (Orang) }\end{array}$ & $\begin{array}{c}\text { Persentas } \\
\mathrm{e} \\
(\%)\end{array}$ \\
\hline 1. & SD & 1 & 7.69 \\
\hline 2. & SMP & 3 & 23.08 \\
\hline 3. & SMA & 7 & 53.85 \\
\hline 4. & PerguruanTinggi & 2 & 15.38 \\
\hline & Jumlah & 13 & 100 \\
\hline
\end{tabular}

Sumber: Diolah Dari Data Primer, 2019
Tabel 3 menunjukkan tingkat pendidikan responden terbanyak terdapat pada tingkat pendidikan SMA dengan dengan jumlah sebanyak 7 orang responden dengan persentase $53.38 \%$, dan persentase terbanyak kedua tingat SMP sebesar $23.08 \%$ dengan jumlah responden 3 orang, persentase perguruan tinggi sebesar $15.38 \%$ dengan responden 2 orang dan pada tingkat SD memiliki persentase $7.69 \%$ dengan jumlah responden 1 orang.

\section{Jumlah Tanggungan Keluarga}

Jumlah tanggungan keluarga yang dimaksud adalah banyaknya orang yang menjadi anggota dalam sebuah keluarga (rumah tangga). Sejalan dengan kebutuhan manusia, dapat dipahami bahwa semakin banyak anggota sebuah keluarga akan semakin besar pula kebutuhan yang akan dipenuhi. Jumlah tanggungan keluarga yang besar dapat menjadi salah satu sebab sebuah rumah tangga menjadi miskin, terutama jika anggota keluarga mayoritas masih berusia non produktif. Dalam memenuhi kebutuhan tersebut tentu dibutuhkan kerja keras agar memperoleh pendapatan yang besar, guna memenuhi kebutuhan seluruh anggota keluarga. Untuk jumlah tanggungan anggota keluarga responden di Desa Tonsewer Selatan Kecamatan Tompaso Barat dapat dilihat pada Tabel 4.

Tabel 4. Jumlah Tanggungan Keluarga Responden

\begin{tabular}{cccc}
\hline No & $\begin{array}{c}\text { Jumlah } \\
\text { Tanggungan } \\
\text { (Orang) }\end{array}$ & $\begin{array}{c}\text { Jumlah } \\
\text { Responden } \\
\text { (Orang) }\end{array}$ & $\begin{array}{c}\text { Presentase } \\
(\%)\end{array}$ \\
\hline 1. & $1-2$ & 10 & 76.92 \\
2. & $3-4$ & 3 & 23.08 \\
\hline & Jumlah & 13 & 100.00 \\
\hline
\end{tabular}

Sumber: Diolah Dari Data Primer, 2019

Tabel 4 menunjukkan bahwa jumlah tanggungan keluarga yang terbesar adalah antara 1-2 tanggungan dengan persentase sebanyak 76,92 persen dengan jumlah responden 10 orang dan untuk jumlah tanggungan yang berada pada antara 3-4 memiliki persentase 23,08 persen dengan jumlah responden 3 orang. 


\section{Data Lahan}

\section{Luas Lahan yang Dibebaskan}

Lahan yang dibebaskan adalah perubahan fungsi sebagian atau seluruh kawasan lahan dari fungsi semula menjadi fungsi lain terhadap lingkungan dan potensi lahan itu sendiri. Sebanyak tiga belas responden dalam penelitian ini adalah petani yang sebelum mengalihfungsikan lahannya ke non pertanian. Luas lahan yang dibebasakan oleh responden dapat dilihat dalam Tabel 5.

\begin{tabular}{|c|c|c|c|}
\hline No & $\begin{array}{c}\text { Luas Lahan } \\
\text { yang } \\
\text { Dibebaskan } \\
\left(\mathrm{M}^{2}\right)\end{array}$ & $\begin{array}{c}\text { Harga } \\
\text { Lahan/ } \\
\left(\mathbf{M}^{2}\right)\end{array}$ & $\begin{array}{c}\text { Yang } \\
\text { Dibayarkan } \\
\text { (Rp) }\end{array}$ \\
\hline 1. & 3.262 & 100.000 & 326.200 .000 \\
\hline 2. & 1.831 & 100.000 & 183.100 .000 \\
\hline 3. & 11.640 & 100.000 & 1.164 .000 .000 \\
\hline 4. & 6.313 & 100.000 & 631.300 .000 \\
\hline 5. & 1.742 & 100.000 & 174.200 .000 \\
\hline 6. & 3.874 & 100.000 & 387.400 .000 \\
\hline 7. & 108 & 100.000 & 10.800 .000 \\
\hline 8. & 354 & 100.000 & 35.400 .000 \\
\hline 9. & 885 & 100.000 & 88.500 .000 \\
\hline 10. & 1.791 & 100.000 & 179.100 .000 \\
\hline 11. & 5.230 & 100.000 & 523.000 .000 \\
\hline 12. & 2.044 & 100.000 & 204.400 .000 \\
\hline 13. & 42.886 & 100.000 & 4.288 .600 .000 \\
\hline Total & 81.960 & 100.000 & 8.195 .900 .000 \\
\hline
\end{tabular}

Tabel 5 menunjukkan luas lahan yang dibebaskan oleh para mantan pemilik memiliki varian luas yang berbeda dari lahan yang kecil hingga yang besar, dapat dilihat lahan terbesar yang dibebaskan adalah $42.886 \mathrm{~m}^{2}$ dengan uang ganti rugi yakni $\mathrm{Rp}$ 4.288.600.000,- dan lahan terkecil yang dibebaskan yakni $108 \mathrm{~m}^{2}$ dengan uang ganti rugi sebesar Rp10.800.000.

\section{Harga Lahan per Meter}

Harga lahan adalah penilaian atas lahan yang diukur berdasarkan harga nominal dalam satuan uang untuk satu satuan luas tertentu. Faktor yang berpengaruh terhadap tinggi rendahnya nilai lahan yaitu penggunaan lahan. Jarak lahan dengan pusat kegiatan manusia semakin dekat maka nilai lahan akan semakin tinggi. Dalam penelitian dapat dilihat dalam Tabel 8 dari hasil penelitian dilapangan terhadap responden harga atau nilai lahan per meter adalah sama rata disetiap responden yang dibeli oleh PT. Pertamina untuk pembangunan proyek, karena lahan yang dibebaskan adalah lahan perkebunan yang cukup jauh dari pemukiman maka dengan kesepakatan bersama antara Pemilik dan PT. Pertamina lahan tersebut dapat dibeli oleh PT.Pertamina dengan harga Rp100.000,- per meter.

\section{Luas Lahan yang dimiliki Responden}

Luas lahan responden adalah area lahan yang diusahakan oleh petani dan dinyatakan dalam hektar (Ha). Luas penguasaan lahan pertanian merupakan sesuatu yang sangat penting dalam proses produksi ataupun usaha tani, luas lahan akan mempengaruhi besarnya produksi yang diusahakan dan kesejahteraan yang akan mereka peroleh. Beberapa petani yang mempunyai lahan kecil dalam penelitian ini dikarenakan lahan pertanian yang berasal dari orang tua yang diwariskan kepada mereka (petani), sehingga mengharuskan petani membagi luas lahan garapan dengan kerabat terdekatnya. Luas lahan sekarang yang dimiliki oleh responden dapata dilihat pada Tabel 6.

\begin{tabular}{lccr}
\multicolumn{4}{l}{ Tabel 6. Luas Lahan yang Dimiliki } \\
\hline \multirow{2}{*}{ No } & $\begin{array}{c}\text { Luas Lahan } \\
\text { (Ha) }\end{array}$ & $\begin{array}{c}\text { Jumlah Responden } \\
\text { (Orang) }\end{array}$ & $\begin{array}{c}\text { Presentase } \\
(\%)\end{array}$ \\
\hline 1. & $0,1-1$ & 8 & 61.54 \\
2. & $1,1-2$ & 3 & 23.08 \\
3. & $2,1-3$ & - & 0 \\
4. & $3,1-4$ & 2 & 15.38 \\
\hline \multicolumn{5}{r}{ Sumber: Diolah Dari Data Primer, 2019} & 100 \\
\hline
\end{tabular}

Tabel 6 menunjukkan bahwa jumlah luas lahan yang dimiliki oleh responden setelah membebaskan lahannya baik itu lahan sisa dari hasil pembembasan maupun lahan baru yang di beli oleh responden. Dapat dilihat presentase paling besar yakni 61,54 persen 
dengan jumlah 8 responden yang memiliki luas lahan 0,1-1 Ha. Kemudian persentase 23,08 persen dengan 3 reponden memiliki luas lahan 1,1-2 Ha dan responden dengan luas lahan 3,14 Ha memiliki persentase 15,38 persen dengan jumlah 2 responden.

\section{Nilai Lahan yang ada di Desa Tonsewer Selatan}

Nilai Lahan meruupakan pengukuran yang di dasarkan kepada kemampuan lahan secara ekonomis dalam hubungannya dengan produktifitas dan strategi ekonomi. Lahan memiliki nilai ekonomi yang bebeda-beda. Harga lahan sangat dipengaruhi oleh parameter-parameter nilai lahan, dimana semakin strategis lokasi lahan dengan fasilitasfasilitas yang ada maka nilai lahan akan semakin tingggi.

Dalam penelitian ini harga disetiap lahan dibagi dalam tiga lokasi yaitu lahan dengan harga Rp 6.000,- per meter ini berlokasi di atas atau dipuncak yang jauh dari pemukiman yang memiliki lahan yang curam dan tidak rata, untuk lahan dengan harga Rp 8.500,- per meter yang belokasi di dekat pemukiman yang memiliki lahan yang rata dan yang dekat sumber air dan akses jalan yang sudah bagus. Sedangkan lahan dengan harga Rp 10.000,- per meter adalah lahan yang berlokasi dekat dengan proyek yang akan dibangun oleh PT. Pertamina dikarenakan ada asumsi dari pihakpihak tertentu yang akan memperluas lokasi proyek.

\section{Faktor yang Mendorong Pemilik Menjual Lahan}

Dalam hal ini lahan yang dibebaskan merupakan lahan pertanian yang merupakan mata pencaharian oleh masyarakat Desa Tonsewer Selatan untuk memenuhi kebutuhan. Dikarenakan adanya proyek yang dilakukan oleh PT. Pertamina kepemilikan lahan tersebut dialihfungsikan dengan musyawarah antara pemilik lahan dan PT. Pertamina untuk mengetahui harga ganti rugi yang akan diterima oleh pemilik lahan tersebut. Dengan adanya negosiasi ini sehingga kedua belah pihak sepakat untuk melakukan pembebasan lahan. Selain itu faktor ekonomi juga mendorong pemilik menjual lahan untuk memenuhi kebutuhan hidup.

\section{Pemanfaatan Uang \\ Hasil Pembebasan Lahan}

Tabel 8 menunjukkan responden paling besar menggunakan uang hasil pembebasan lahan untuk modal usaha yaitu 13 responden dengan persentase 100 persen, kemudian responden yang menggunakan uang hasil pembebasan lahan untuk membeli lahan baru 11 responden dengan persentase 84,62 persen, responden yang menggunakan uang hasil pembebasan lahan untuk di tabung yaitu jumlah responden 11 memiliki persentase 84,62 persen, responden yang menggunakan uangnya untuk membeli kendaraan 7 respoden memiliki persentase 53,85 persen, responden yang menggunakan uang hasil pembebasan lahannya untuk merenovasi rumah yaitu 5 responden dengan persentase 38,46 persen dan yang menggunakan uang untuk kebutuhan sehari-hari yaitu 2 responden dengan persentase 15,38 persen.

Tabel 8. Pemanfaatan Uang Hasil Pembebasan Lahan

\begin{tabular}{llcc}
\hline No & $\begin{array}{c}\text { Pemanfaatan Uang } \\
\text { Hasil Pembebasan }\end{array}$ & $\begin{array}{c}\text { Jumlah } \\
\text { Responden } \\
\text { (Orang) }\end{array}$ & $\begin{array}{c}\text { Presentase } \\
(\%)\end{array}$ \\
\hline 1. & Membeli Lahan Baru & 11 & 84.62 \\
2. & Modal Usaha & 13 & 100 \\
3. & Renovasi Rumah & 5 & 38.46 \\
4. & Tabungan & 11 & 84.62 \\
5. & Membeli Kendaraan & 7 & 53.85 \\
6. & Kebutuhan Sehari-Hari & 2 & 15.38 \\
\hline \multicolumn{4}{l}{ Sumber: Diolah Dari Data Primer, 2019 }
\end{tabular}

Proses pemberian uang ganti rugi ini dilakukan secara langsung atau tunai sesuai besar luas lahan yang telah dibebesakan oleh pemilik sebelumnya. Pemanfaatan uang hasil dari pembebasan lahan dimanfaatkan sebagai:

1. Pemilik menggunakannnya sebagai modal usaha seperti untuk berdagang di pasar dan untuk modal pertanian (untuk membeli bibit tanaman, pupuk, pestisida maupun alat-alat pertanian).

2. Melakukan pembelian lahan yang baru. Pembelian tanah ini dilakukan di perkebunan Desa Tonsewer sendiri maupun diluar Desa Tonsewer. 
3. Melakukan deposit ke bank atau ditabung untuk kebutuhan beberapa tahun yang akan datang.

4. Melakukan pembelian kendaraan baik motor maupun mobil yang digunakan untuk kebutuhan sehari-hari ataupun untuk jasa transportasi.

5. Membangun dan merenovasi rumah agar menjadi lebih baik.

6. Uang yang diterima oleh pemilik yang memiliki lahan kecil menggunakan uang tersebut untuk memenuhi kebutuhan seharihari.

Pembebasan lahan telah mempengaruhi aspek sosial ekonomi dari masyarakat Desa Tonsewer Selatan khususnya yang telah melakukan pembebasan lahan, karena dengan adanya proyek oleh PT. Pertamina ini membuat pemilik lahan menjadi lebih baik di sisi ekonomi dan memberikan keuntungan yang besar bagi pemilik lahan dan mereka dapat memenuhi kebutuhan sehari-hari.

\section{KESIMPULAN DAN SARAN}

\section{Kesimpulan}

Hasil penelitian yang dilakukan menyatakan nilai lahan yang dibebaskan lebih tinggi nilainya dari pada nilai lahan yang ada di Desa Tonsewer Selatan. Dengan adanya kesepakatan bersama antara PT. Pertamina dengan responden maka harga lahan yang dibeli oleh PT. Pertamina yakni Rp 100.000,--m². Uang hasil pembebasan lahan digunakan responden untuk modal usaha, membeli lahan baru, ditabung, membeli kendaraan, merenovasi rumah, dan untuk memenuhi kebutuhan seharihari.

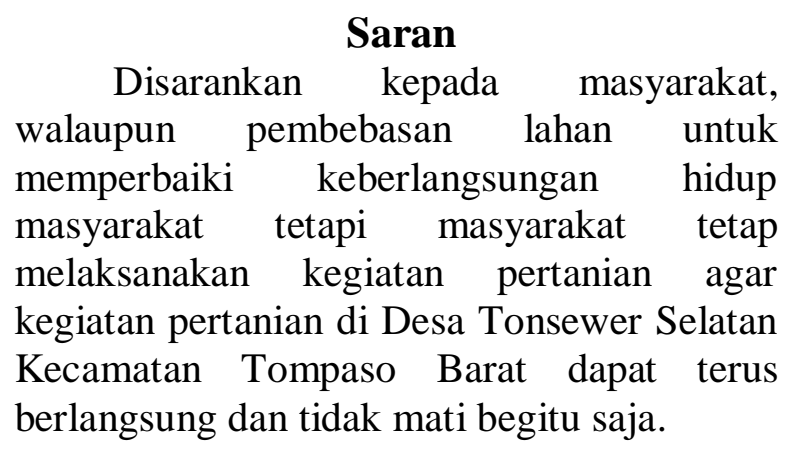

\section{Saran}


Rahman. 2015. Ke Arah Melestarikan Alam Bina untuk Generasi Masa Hadapan (Penerbit USM). Penerbit USM.

Wibisono, P. A., \& Harun, S. H. 2018. Pengaruh Konversi Lahan Pertanian Menjadi Perindustrian Terhadap Sumber Daya Air Tanah di Kecamatan Grogol Kabupaten Sukoharjo (Doctoral dissertation, Universitas Muhammadiyah Surakarta).
Yunus, M. 2017. Arahan Pola Pemanfaatan Lahan Sektor Pertanian Untuk Meningkatkan Pendapatan Masyarakat (Studi Kasus Kecamatan Paleteang Kabupaten Pinrang) (Doctoral dissertation, Universitas Islam Negeri Alauddin Makassar). 